
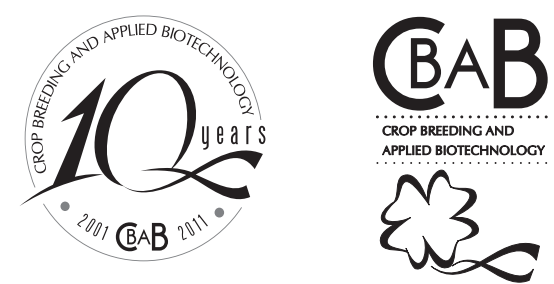

\title{
Genetic divergence among Psidium accessions based on biochemical and agronomic variables
}

\author{
Carlos Antonio Fernandes Santos ${ }^{1 *}$, Luiz Cláudio Corrêa ${ }^{2}$ and Soniane Rodrigues da Costa ${ }^{1}$
}

Received 9 September 2010

Accepted 1 November 2010

\begin{abstract}
Sixty-nine Psidium accessions collected in six Brazilian states were analyzed by two non-hierarchical clustering methods and principal components (PC), to provide orientation for breeding programs. The variables ascorbic acid, $\beta$-carotene, lycopene, total phenols, total flavonoids, antioxidant activity, titrable acidity, soluble solids, total soluble sugars, moisture content, lateral and transversal fruit diameter, fruit pulp and seed weighs, and plant fruit number and weight were analyzed. Specific groups were observed for the araçazeiros accessions, by the Tocher and the k-means methods, as well as by the three-dimensional dispersion of the four PCs. The clustering separated accessions of araçazeiros from the guava. There was no specific grouping in terms of States of origin, indicating the absence of barriers in the guava propagation accessions. Analyses suggested the collection of a greater number of guava germplasm samples from a smaller number of regions and divergent accessions with high nutritional compound levels to develop new cultivars.
\end{abstract}

Key words: Psidium guajava; antioxidants; nutritional compounds; multivariate analysis.

\section{INTRODUCTION}

In Brazil, in 2007 guava ranked $11^{\text {th }}$ in cultivated area and production value, $10^{\text {th }}$ in yield and $5^{\text {th }}$ in productivity among other important fruits such as orange, banana, grapes, papaya, apple, mango, tangerine, passion fruit, lemon, peach, persimmon, avocado, fig, pear, and quince. The main guava-producing states in 2007 were Pernambuco, São Paulo, Goiás, and Bahia, which together accounted for almost $75 \%$ of the national production (http://www. sidra.ibge.gov.br).

Guava (Psidium guajava) belongs to the Myrtaceae family, with approximately 130 genera and 3000 species of trees and shrubs distributed mainly in the tropics and subtropics (http://delta-intkey.com). Guava is native to northern South America and widely distributed in the tropical regions of America (Risterucci et al. 2005). Other fruits of the genus Psidium, with about 150 species, are the Brazilian guava called araçazeiros, a term that refers to native Psidium species, with $P$. cattleyanum Sat., $P$. incanesces Martius, $P$. gradiflorum Martius, and $P$. arboretum Vell (Raseira and Raseira 1996). Although not as interesting as guava, Brazilian guava species have some important attributes such as earliness, tolerance to certain pests and diseases and exotic fruit flavor (Manica 2000).

Despite being regarded as one of the diversity centers of guava and araçazeiros (Soares-Silva and Proença 2008), Brazil has few research institutions with gene banks for this Psidium species which, in total, have compiled 310 accessions and 174 accessions of Brazilian guava. Important cultivars for the Brazilian guava agribusiness are Paluma, Rich, Sassaoka and Pedro Sato, which were developed

\footnotetext{
${ }^{1}$ Embrapa Semiárido, C.P. 23, 56.302-970, Petrolina, PE, Brazil.*E-mail: casantos@ @patsa.embrapa.br

${ }^{2}$ Universidade Estadual Paulista (Unesp), Campus de Botucatu, 18.618-000, Botucatu, SP, Brazil
} 
from selections of producers or research institutions in open-pollinated seed orchards (Pommer et al., 2006).

The available collections of guava and araçazeiros in Brazil have been almost exclusively characterized for agronomic traits and only few studies focused on the chemical characterization, e.g., the paper of Lima et al. (2002). The importance of studies of functional compounds in guava can be exemplified by lycopene, the carotenoid responsible for the red color of the guava pulp. According to Yan et al. (2006), lycopene is considered an excellent antioxidant, with a high resistance potential to diseases such as prostate cancer and arteriosclerosis. According to these authors, the lycopene level found in the guava cultivar Paluma is the double found in tomatoes.

For Pereira and Nachtigal (2003) the aim of the improvement of guava characteristics would be an average fruit weight $>100 \mathrm{~g}$, a red pulp and pulp yield $>70 \%$, soluble solids $>10^{\circ}$ Brix, sugar/acidity ratio $>11$, vitamin C content of around $100 \mathrm{mg}$ of ascorbic acid per $100 \mathrm{~g}$ of pulp and a minimum production of $30 \mathrm{tha}^{-1}$.

The agronomic descriptions of guava collections in Brazil (Souza Junior et al. 2002, Gonzaga Neto 2002, Santos et al. 2008, Silva Junior et al. 2008) did not establish estimates of genetic distances between accessions, to support controlled crossings and the development of cultivars with improved traits, including higher levels of nutritional compounds. In the international literature divergence studies have been published based on morphological traits for collections of Mexican (Hernandez-Delgado et al. 2007) and Cuban accessions (Rodriguez et al. 2004).

The purpose of this study was to group accessions belonging to the Psidium gene bank of Embrapa Semiarid by multivariate techniques based on biochemical and agronomic variables, to provide orientation for genetic breeding programs of the genus Psidium.

\section{MATERIAL AND METHODS}

Fruits of 59 guava (P. guajava) and 10 Brazilian guava or araçazeiros (Psidium spp.) accessions of the field germplasm bank of Psidium (Table 1) installed in the experimental field Bebedouro of Embrapa Semiarid were collected. The accessions were sampled at physiological maturity in six different Brazilian states, as described by Santos et al. (2008). Each accession was established in the field from four-month-old seed-grown seedlings, in January 2007. The data of six plants were evaluated, from two replications with three plants each. The accessions were managed according to the regional practices for commercial guava production, using a drip irrigation system in a plant spacing of $4.0 \mathrm{~m} \times 4.0 \mathrm{~m}$. To induce fruiting, the plants were pruned in August 2008 and harvest began in December 2009.

Psidium accessions were characterized for 16 variables. Antioxidant variables: ascorbic acid (ASA), $\mathrm{mg} \mathrm{g}^{-1} \mathrm{MF}$, determined by the method proposed by Carvalho et al. (1990); $\beta$-carotene(BCT), mg $100 \mathrm{~g}^{-1} \mathrm{MF}$, and lycopene (LYC), mg $100 \mathrm{~g}^{-1} \mathrm{MF}$, according to the methodology used by Nagata and Yamashita (1992); total phenols (PHEN), $\mathrm{mg} \mathrm{g}^{-1}$ EAG MF, determined as proposed by Alothman et al. (2009), total flavonoids (FLV), rutin mg $100 \mathrm{~g}^{-1} \mathrm{MF}$, based on the method of Lombard et al. (2002), antioxidant activity (AOX), AAS $\mathrm{mg} \mathrm{g}^{-1} \mathrm{MF}$, determined as proposed by Mensor et al. (2001).

Biochemical variables: acidity, \% citric acid was determined by titration method proposed by the Instituto Adolfo Lutz (1985); soluble solids (\%), ${ }^{\circ}$ Brix, determined using a digital refractometer, according to standard techniques of the Instituto Adolfo Lutz (1985), total soluble sugars, \% M, quantification by the anthrone method (McCready et al. 1950); moisture content, $\% \mathrm{H}_{2} \mathrm{O}$ determined as weight of oven-dried (under forced air circulation at $65^{\circ} \mathrm{C}$ to constant weight) fresh fruit.

Variables of agronomic characters: lateral fruit diameter, mm; transversal fruit diameter, $\mathrm{mm}$; yield per plant, g; seed weight per fruit, g; number of fruits per plant and pulp weight per fruit, g, were obtained from samples taken for these variables every two or three days, during the production cycle.

The data were statistically analyzed by: 1 . analysis of variance, 2. principal component analysis, after standardizing the data to exclude the effect of different measurement scales of variables, using SAS (SAS 1989), 3. cluster analysis by the modified Tocher method (Vasconcelos et al. 2007), based on Mahalanobis' generalized distances, supported by software Genes (Cruz 2008), 4. cluster analysis with standardized data, according to the (SAS) FASTCLUS Procedure (1989), with the formation of six similar groups corresponding to the number of states sampled. The FASTCLUS Procedure uses a method called nearest centroid sorting, where the dissimilarity measure is the mean Euclidean distance, which is a k-means clustering method (SAS 1989).

\section{RESULTS AND DISCUSSION}

In the analysis of variance a significant effect $(\mathrm{P}<0.01)$ was observed for each of the 16 variables by test $\mathrm{F}$, 
Genetic divergence among Psidium accessions based on...

Table 1. Identification of 69 accessions of guava (G) and Brazilian guava or araçazeiro (A) of the Psidium genebank

\begin{tabular}{|c|c|c|c|c|c|}
\hline Accession & Origin & State & Accession & Origin & State \\
\hline G01MA & Caxias & MA & A45PE & Escada & PE \\
\hline G02MA & Caxias & MA & G46PE & Escada & PE \\
\hline G03MA & Coelho Neto & MA & G47PE & Riacho das almas & $\mathrm{PE}$ \\
\hline G05MA & Buriti & MA & G48SE & Nossa Senhora da Glória & SE \\
\hline G07MA & Mata Roma & MA & G49SE & Dores & SE \\
\hline A08MA & Mata Roma & MA & G50SE & Capela & SE \\
\hline G10MA & Presidente Vargas & MA & G51SE & Capela & SE \\
\hline G11MA & Presidente Vargas & MA & G52SE & Capela & SE \\
\hline G12MA & Cajari & MA & G53SE & Japoratuba & SE \\
\hline G13MA & Viana & MA & G54SE & Japoratuba & SE \\
\hline G14MA & Pindarí & MA & G55SE & Pirambu & SE \\
\hline G15MA & Bom Jardim & MA & G58SE & SantaLuzia & SE \\
\hline G16MA & Bom Jardim & MA & G59SE & Umbamba & SE \\
\hline G17MA & Santa Luzia & MA & G60SE & Umbamba & SE \\
\hline G18MA & Santa Luzia & MA & G61SE & Riachão dos Dantas & SE \\
\hline G19MA & Graiaú & MA & G65RO & Ji-paraná & RO \\
\hline G20MA & Tuntum & MA & G66RO & Ouro Preto do Oeste & RO \\
\hline G21MA & Tuntum & MA & G67RO & Jaru & RO \\
\hline G22MA & Presidente Dutra & MA & G68RO & Buritis & RO \\
\hline G23MA & Presidente Dutra & MA & G69RO & Buritis & RO \\
\hline G24MA & Colinas & MA & G70RO & Buritis & RO \\
\hline G25MA & Colinas & MA & G73RO & Ariquemes & RO \\
\hline G26MA & Paibano & MA & A78RO & Candeias do Jamarí & RO \\
\hline G28PI & Colônia Gurqueia & PI & A79RO & PortoVelho & RO \\
\hline A29PI & Eliseu Martins & PI & A80RO & PortoVelho & RO \\
\hline G30PI & Canto do Buriti & PI & G81RO & PortoVelho & RO \\
\hline G31PI & Brejo do Piauí & PI & G83AM & ItacoatiA & $\mathrm{AM}$ \\
\hline G32PE & Ibimirim & $\mathrm{PE}$ & G87AM & Iranduba & $\mathrm{AM}$ \\
\hline G33PE & Ibimirim & PE & G92AM & Manacapuru & $\mathrm{AM}$ \\
\hline G34PE & Ibimirim & PE & G94AM & Autazes & $\mathrm{AM}$ \\
\hline G35PE & Ibimirim & PE & G95AM & Autazes & $\mathrm{AM}$ \\
\hline G38PE & Pesqueira & PE & G96AM & Autazes & $\mathrm{AM}$ \\
\hline A42PE & Escada & PE & G98AM & Autazes & $\mathrm{AM}$ \\
\hline A43PE & Escada & PE & A100AM & Careiro & $\mathrm{AM}$ \\
\hline A44PE & Escada & $\mathrm{PE}$ & & & \\
\hline
\end{tabular}

indicating the existence of phenotypic variability in the 69 Psidium accessions studied. In the analysis of variance performed only with the guava accessions the effect was also significant $(\mathrm{P}<0.01)$ by the $\mathrm{F}$ test for all variables, except moisture content $(\mathrm{p}<0.05)$, indicating the existence of phenotypic variability among the 59 Psidium guava accessions under study.

The 10 araçazeiros accessions were grouped in a specific cluster when analyzed by the k-means (Table 2), while in the Tocher analysis, these same 10 accessions were grouped into two clusters, one with seven and the other with three accessions (Table 3). Results of this study indicate that the Brazilian guava showed biochemical and agronomic traits that distinguish them from guava accessions, which may be the result of the intense artificial selection in guava for the purpose of agronomic cultivation and fruit quality-related traits. Analyzing the araçazeiros and guava accessions from different Brazilian states for morphological traits, Santos et al. (2008) concluded that the fruit traits e.g., pulp color and fruit size, were the most influenced by the artificial selection in guava.

As discussed by Raseira and Raseira (1996), the term araçazeiro refers to several Psidium species with wide distribution in Brazil (Soares-Silva and Proença 2008). In the analysis by the k-means clustering method, all araçazeiros were grouped into a single cluster (Table 2), suggesting that the differences among araçazeiros ecotypes were smaller than of araçazeiros compared to guava accessions. 
CAF Santos et al.

Table 2. Grouping of accessions of the Psidium gene bank of Embrapa Semiarid, analyzed for 16 biochemical and agronomic traits, distributed in six groups by the k-means clustering method based on the Euclidean mean distance

\begin{tabular}{lcl}
\hline Group & $\begin{array}{c}\text { Number of } \\
\text { accessions per group }\end{array}$ & \\
\hline Group1 & 14 & $\begin{array}{l}\text { G02MA, G05MA, G07MA, G11MA, G14MA, G16MA, G17MA, G18MA, G22MA, G23MA, } \\
\text { G31PI, G55SE, G73RO, G98AM }\end{array}$ \\
Group2 & 10 & A08MA, A100AM, A29PI, A42PE, A43PE, A44PE, A45PE, A78RO, A79RO, A80RO \\
Group3 & 05 & G01MA, G03MA, G10MA, G38PE, G47PE \\
Group4 & 13 & G12MA, G34PE, G51SE, G60SE, G66RO, G67RO, G68RO, G69RO, G81RO, G83AM, G92AM, \\
Group5 & 08 & G95AM, G96AM \\
Group6 & 19 & G13MA, G21MA, G24MA, G49SE, G50SE, G54SE, G58SE, G94AM \\
& G48SE, G52SE, G53SE, G59SE, G61SE, G65RO, G70RO, G87AM \\
\hline
\end{tabular}

Table 3. Grouping of accessions of the Psidium gene bank of Embrapa Semiarid, based on 16 biochemical and agronomic traits, distributed in 10 groups by the modified clustering method of Tocher based on Mahalanobis' distance

\begin{tabular}{lcl}
\hline Group & $\begin{array}{c}\text { Total accessions } \\
\text { per group }\end{array}$ & \multicolumn{1}{c}{ Accessions } \\
\hline Group1 & 34 & G26MA, G30PI, G25MA, G19MA, G50SE, G05MA, G58SE, G32PE, G55SE, G70RO, G20MA, \\
& & $\begin{array}{l}\text { G87AM, G65RO, G69R0, G67RO, G46PE, G92AM, G61SE, G83AM, G98AM, G12MA, G54SE, } \\
\text { G73RO, G15MA, G18MA, G13MA, G21MA, G48SE, G16MA, G59SE, G94AM, G52SE, G51SE, } \\
\text { G66RO, }\end{array}$ \\
Group2 & 07 & A44PE, A45PE, A29PI, A43PE, A79RO, A78RO, A43PE \\
Group3 & 06 & G95AM, G96AM, G68RO, G60SE, G34PE, G81RO \\
Group4 & 07 & G07MA, G22MA, G11MA, G31PI, G14MA, G01MA, G10MA \\
Group5 & 03 & G28PI, G53SE, G35PE \\
Group6 & 04 & G38PE, G47PE, G03MA, G23MA \\
Group7 & 03 & A80RO, AO8MA, A100AM \\
Group8 & 02 & G24MA, G49SE \\
Group9 & 02 & G02MA, G17MA \\
Group 10 & 01 & G33PE \\
\hline
\end{tabular}

The formation of two araçazeiros groups in the Tocher cluster analysis (Table 3) suggests that there were probably different species or even variability within a single species, considering that the total number of Brazilian guava species was not determined in this study. In view of the presence of different araçazeiros species in Brazil, this analysis indicates that the biological significance of the Tocher analysis was greater than of the k-means. In both analyses, results indicated that the differences in agronomic and biochemical variables were sufficient to form specific groups of araçazeiros and guava accessions.

The groups of Psidium accessions formed by the two clustering methods showed different results, with no coincidence: the 13 accessions clustered in group 4 by the k-means method were distributed in groups 4 and 1 by the Tocher method (Tables 2 and 3). Many clustering methods are biased in relation to group size, shape and dispersion; the k-means method, for example, tends to find groups with an approximate number of elements (SAS 1989), as observed in this study. The Tocher method clustered a first group with 34 accessions, in other words, $50 \%$ of the accessions formed a single group and group 10 contained only one plant, indicating limitations to identify differences between accessions. As concluded in the review of Fonseca et al (2004), the application of the discriminant function technique can minimize the probability of genotype misclassification, in the case of a preexisting classification study.

There were no specific clusters for sampling states of $P$. guajava accessions by the two grouping methods (Tables 2 and 3). Not even by the k-means method, where the number of six clusters had been defined in reference to the number of sampled Brazilian states. The absence of relationships between clusters and germplasm sampling 
regions has been reported for traits influenced by environmental conditions, such as phenotypic, for Stipa lagascae and Artocarpus heterophyllus (Visser and Reheul 2001, Jagadeesh et al. 2007) or for species exposed to longterm selection, such as Solanum tuberosum (Rio et al. 2004). It should be noted that the guava genotypes were subject to selection for multiple traits and may have been vegetatively dispersed from one location to another, for various reasons, resulting in the formation of groups independent from the collection site. Although Brazil is considered an area of guava diversity (Risterucci et al. 2005), no naturally occurring guava plants were found among the accessions of the collection studied; guava was always associated with human presence, growing in backyards, on road sides or beside old houses, among other sites.

The accumulated variation of the three principal components was $69 \%$, indicating a restricted suitability for a three-dimensional dispersion model of Psidium accessions (Table 4). When the four principal components are considered, accumulated variation was $76 \%$, indicating good suitability, without major distortion of accessions in three-dimensional diagrams, as discussed by Cruz and Regazzi (1994). The 10 araçazeiros accessions formed a specific group in the three-dimensional diagrams (Figures $1 \mathrm{~A}$ and $\mathrm{B})$, suggesting a smaller differentiation among araçazeiros than among guava accessions, probably due to the process of artificial selection with the latter, as observed in the analysis of non-hierarchical grouping methods (Tables 2 and 3 ).

In the principal component analysis, the variables with highest weight of eigenvalues which explained most of the variation among Psidium accessions were transversal fruit diameter, total antioxidant activity, number of fruits per plant and total phenols. The variables with highest weight of eigenvalues, which explain least of the variation among Psidium accessions, were pulp weight per fruit and total flavonoids, and are therefore dispensable (Table 4). Cruz and Regazzi (1994) reported that traits that are relatively invariant among accessions and/or redundant due to their high correlation with other characters are dispensable or less important in divergence studies.

This is the first study to apply multivariate techniques to analyze genetic diversity in guava and araçazeiros accessions in Brazil. Hernandez-Delgado et al. (2007) analyzed 52 Psidium accessions in Mexico with 50 qualitative and quantitative characters and reported that the analysis of 14 principal components explained less than $30 \%$ of the total variation in the characterization of the accessions, which is well below the value observed in this study. Sanabria et al. (2005) reported that the first three principal components explained $72 \%$ of the total

Table 4. Eigenvalues, accumulated percentage and variables associated to the eigenvectors with highest absolute value for 16 principal components in 69 accessions of the Psidium, analyzed for 16 biochemical and agronomic traits

\begin{tabular}{|c|c|c|c|}
\hline $\begin{array}{l}\text { Principal } \\
\text { component }\end{array}$ & Eigenvalues & Accumulated & $\begin{array}{l}\text { Variables associated to the eigenvectors with highest } \\
\text { absolute value }\end{array}$ \\
\hline 1 & 5.83 & 0.364 & Transversal fruit diameter \\
\hline 2 & 3.51 & 0.584 & Total antioxidant activity \\
\hline 3 & 1.73 & 0.692 & Number of fruits per plant \\
\hline 4 & 1.13 & 0.763 & Total phenols \\
\hline 5 & 0.83 & 0.815 & Lycopene \\
\hline 6 & 0.75 & 0.862 & Ascorbic acid \\
\hline 7 & 0.60 & 0.900 & Total soluble sugars \\
\hline 8 & 0.43 & 0.927 & Titrable acidity \\
\hline 9 & 0.34 & 0.949 & Soluble solids \\
\hline 10 & 0.26 & 0.965 & Ascorbic acid \\
\hline 11 & 0.20 & 0.978 & Soluble solids \\
\hline 12 & 0.12 & 0.986 & B-carotene \\
\hline 13 & 0.08 & 0.991 & Total flavonoids \\
\hline 14 & 0.06 & 0.995 & Pulp weight per fruit \\
\hline 15 & 0.04 & 0.998 & Pulp weight per fruit \\
\hline 16 & 0.03 & 1.000 & Pulp weight per fruit \\
\hline
\end{tabular}


CAF Santos et al.
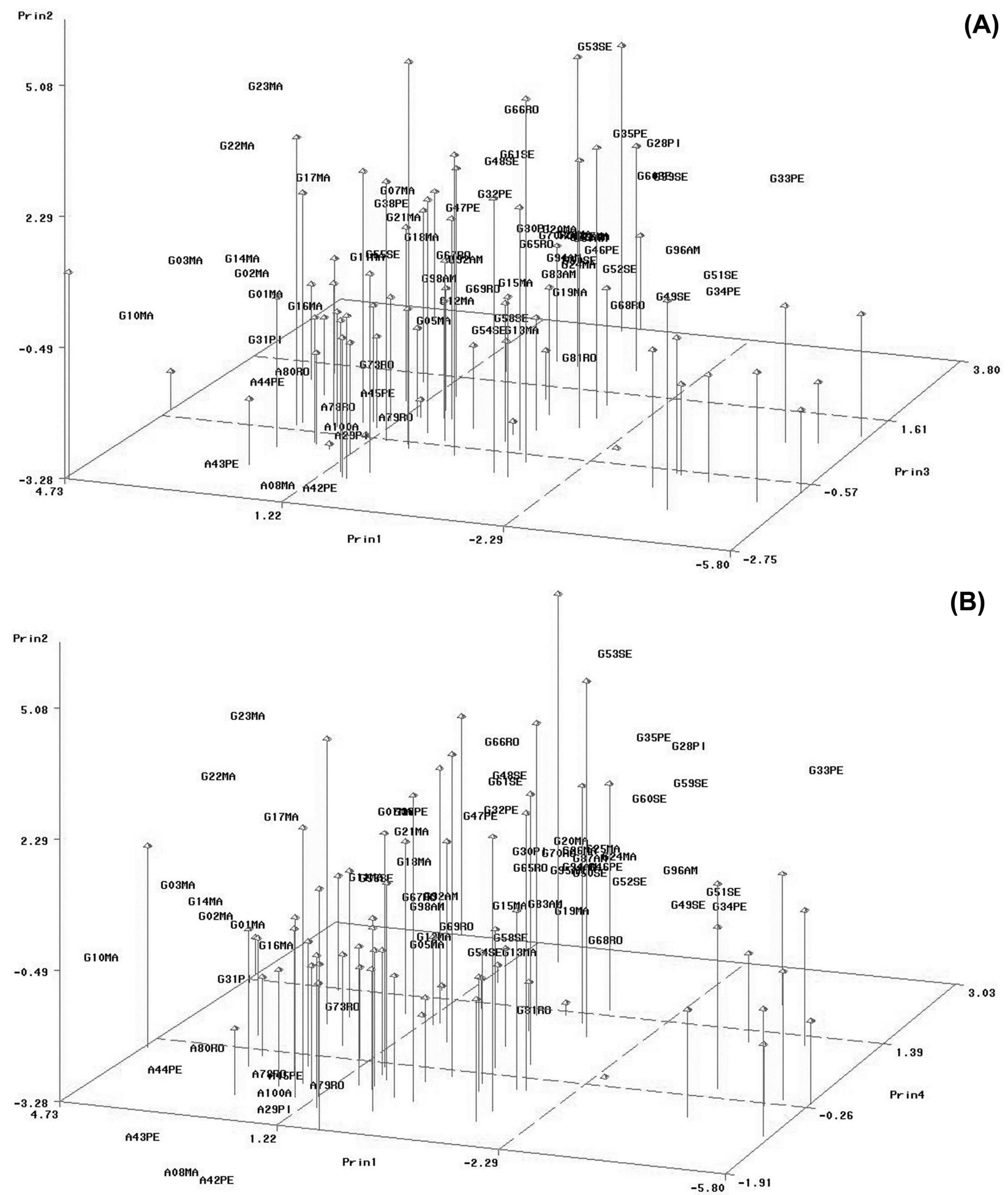

Figure 1. Dispersion diagram based on the principal components prin1, prin2 and prin3 (A) and prin1, prin2 and prin4 (B) of 69 accessions of the Psidium, analyzed for 16 biochemical and agronomic traits. 
variation in 53 Colombian accessions analyzed with 17 qualitative characters and 9 quantitative traits. In the same paper, the authors reported the formation of three groups, with 24, 12 and 17 accessions per group, and reported no correlation between sampling locations and grouping of accessions.

The multivariate analysis techniques used to separate 69 Psidium accessions were generally effective for the discrimination of araçazeiros from guava accessions, indicating that the selections for guava, the most important species of the genus, were efficient to induce changes in the biochemical and agronomic traits evaluated (Tables 2 and 3; Figures $1 \mathrm{~A}$ and $1 \mathrm{~B}$ ). The groups formed by the two methods of non-hierarchical clustering as well as the dispersion of the four principal components indicated no relationship with the sampling location of both araçazeiros as well as guava accessions. For Psidium germplasm collection activities, the analysis of biochemical and agronomic variables suggests restricted collections of seed germplasm, in a smaller number of regions, with a larger number of samples per region.

The information compiled in this study of genetic divergence along with the levels of antioxidant compounds found in the tested accessions, can be used as a reference in guava breeding programs for cultivars with high levels of antioxidant activity. This property has been reported as important for human health because antioxidant compounds can reduce the damaging effects of free radicals in cells (Leong and Shui 2002) and consequently the predisposition to mutagenic diseases.

For the controlled crosses accessions should be selected that performed consistently different by the two clustering methods, as well as in the dispersion of the first four principal components, associated with higher values for the traits of agronomic and biochemical interest. For example, accessions G03MA, G10MA and G01MA, with highest values for antioxidant activity (AOX), may be suitable for crossings with accessions G73RO, G20MA and G32PE, with highest lycopene contents.

\section{ACKNOWLEDGEMENT}

The authors gratefully acknowledge the financial support from the European Community (GUAVAMAP: FP62003-INCO-DEV-2 No. 015111).

\title{
Divergência genética em acessos de Psidium com base em variáveis bioquímicas e agronômicas
}

\begin{abstract}
RESUMO - Sessenta e nove acessos de Psidium, coletados em seis estados brasileiros, foram analisados para dois métodos não hierárquicos de agrupamento e por componentes principais $(C P)$, visando orientar programas de melhoramento. Foram analisadas as variáveis ácido ascórbico, $\beta$-caroteno, licopeno, fenóis totais, flavonóides totais, atividade antioxidante, acidez titulável, sólidos solúveis, açúcares solúveis totais, teor de umidade, diâmetro lateral e transversal do fruto, peso da polpa e das sementes/fruto, número e produção de frutos/planta. Foram observados agrupamentos específicos para os acessos de araçazeiros no método de Tocher e do k-means e na dispersão tridimensional dos quatro CPs. Os acessos de araçazeiros foram separados dos de goiabeira. Não foi observado nenhum agrupamento específico por estado de coleta, indicando a inexistência de barreiras na propagação dos acessos de goiabeira. As análises sugerem a prospecção de maior número de amostras de germoplasma num menor número de regiões, bem como acessos divergentes com alto teor de compostos nutricionais.
\end{abstract}

Palavras-chave: Psidium guajava, antioxidantes, compostos nutricionais, análise multivariada.

\section{REFERENCES}

Alothman M, Bhat R and Karim AA (2009) Antioxidant capacity and phenolic content of selected tropical fruits from Malaysia, extracted with different solvents. Food Chemistry 115: 785788 .
Carvalho CRL, Mantovani DMB, Carvalho PRN and Moraes RMM (1990) Análises químicas de alimentos. Instituto de Tecnologia de Alimentos, Campinas, 121p. (Manual Técnico).

Cruz CD (2008) Programa Genes - diversidade genética. Editora UFV, Viçosa 2008, 278p. 
Cruz CD and Regazzi AJ (1994) Modelos biométricos aplicados ao melhoramento genético. Editora UFV, 390p.

Gonzaga Neto L (2002) Introdução e avaliação de clones de goiabeira de polpa branca (Psidium guajava L.) na região do Submédio São Francisco. Revista Brasileira de Fruticultura 24: 120123.

Fonseca AFA da, Sediyama T, Cruz CD, Sakiyama NS, Ferrão RG, Ferrão, MAG and Bragança SM (2004) Discriminant analysis for the classification and clustering of robusta coffee genotypes. Crop Breeding and Applied Biotechnology 4: 285-289.

Hernandez-Delgado S, Padilla-Ramýrez JS, Nava-Cedillo A and Mayek-Perez N (2007) Morphological and genetic diversity of Mexican guava germplasm. Plant Genetic Resources: Characterization and Utilization 5: 131-141.

Instituto Adolfo Lutz (1985) Métodos físico-químicos para análise de alimentos. Editora Anvisa, São Paulo, 1020p.

Jagadeesh SL, Reddy BS, Basavaraj N, Swamy GSK, Kirankumar, Laxminarayan H, Raghavan GSV and Kajjidoni ST (2007) Inter tree variability for fruit quality in jackfruit selections of Western Ghats of India. Science Horticulture 112: 382-387.

Leong LP and Shui G (2002) An investigation of antioxidant capacity of fruits in Singapore markets. Food Chemistry 76 $69-75$.

Lima MAC de, Assis JS de and Gonzaga Neto L (2002) Caracterização dos frutos de goiabeira e seleção de cultivares na Região do Submédio São Francisco. Revista Brasileira de Fruticultura 24: $273-276$

Lombard KA, Geoffriau E and Peffley E (2002) Flavonoid quantification in onion by spectrophotometric and high performance liquid chromatography analysis. HortScience 37: 682-695.

Manica I (2000) Frutas nativas, silvestres e exóticas 1. Cinco Continentes, Porto Alegre, 327p.

Pereira FM and Nachtigal JC (2003) Goiabeira. In Bruckner CH (ed.) Melhoramento de fruteiras tropicais. UFV, Viçosa, p. 267-289.

Pommer C, Murakami KRN and Watlington F (2006) Goiaba no Mundo. O Agronômico 58: 22-26.

McCready RM, Guggolz J, Silveira V and Owens HS (1950) Determination of starch and amylase in vegetables. Application to peas. Analytical Chemistry 22: 1156-1158.

Mensor LL, Menezes FS, Leitão GG, Reis AS, Santos TC, Coube CS and Leitão SG (2001) Screening of Brazilian plant extracts for antioxidant activity by the use of DPPH free radical method. Phytotherapy Research 15: 127-130.

Nagata M and Yamashita I (1992) Simple method for simultaneous determination of chlorophyll and carotenoids in tomato fruit. Nippon Shokuhin Kogyo Gakkaishi 39: 925-928.
Raseira MCB and Raseira A (1996) Contribuição ao estudo do araçazeiro: Psidium cattleyanum. Embrapa-CPACT, Pelotas, $93 \mathrm{p}$.

Rio, AH, Bamberg JB, Huaman Z, Salas A and Vega SE (2004) Association of ecogeographical variables and RAPD marker variation in wild potato populations of the USA. Crop Science 41: $870-878$.

Risterucci AM, Duval MF, Rohde W and Billotte N (2005) Isolation and characterization of microsatellite loci from Psidium guajava L. Molecular Ecology Notes 5: 745-748.

Rodrýguez NN, Valdes-Infante J, Becker D, Velazquez B, Coto O, Ritter E and Rohde W (2004) Morphological, agronomic and molecular characterization of Cuban accessions of guava (Psidium guajava L.). Journal of Genetics and Breeding 78: $79-90$.

Sanabria HL, Garcia M, Muñoz J and Diaz H (2005) Caracterización molecular con marcadores RAM de árboles nativos de Psidium guajava (guayaba) en el Valle del Cauca. Acta Agronómica 55: 27-38.

Santos CAF, Castro J M C E, Souza FF, Vilarinho AA, Ferreira FR, Padua JG, Borges RME and Rodrigues MA (2008) Preliminary characterization of Psidium germplasm in different Brazilian eco-geographic regions. Pesquisa Agropecuária Brasileira 43: 437-440.

SAS (1989) SAS/STAT user's guide, Version6, Fourth Edition, Volume 2. SAS Institute Inc., Cary, 1686p.

Silva Junior JF, Bezerra JEF, Lederman IE, Tavares JÁ and Melo Neto ML (2008) Caracterización e evaluación de germoplasma de guayabo (Psidium guajava L.) en la región semiárida del Estado de Pernambuco, Brasil. Caatinga 21: 94-99.

Soares-Silva LH and Proença CEB (2008) A new species of Psidium L. (Myrtaceae) from southern Brazil. Botanical Journal of the Linnean Society 158: 51-54.

Souza Junior EE, Duarte B and Chaves LJ (2002) Estabilidade fenotípica em goiabeira (Psidium guajava $\mathrm{L}$.) com ênfase em peso de fruto, precocidade e período de colheita. Pesquisa Agropecuária Tropical 32: 97-103.

Vasconcelos ES de, Cruz CD, Bhering LL and Resende Junior MFR (2007) Método alternativo para análise de agrupamento. Pesquisa Agropecuária Brasileira 42: 1421-1428.

Visser M and Reheul D (2001) Restoring depleted Tunisian dry lands with native steppic species: where should we source the seeds? Genetic Resources and Crop Evolution48: 567-578.

Yan LY, Teng LT and Jhi TJ (2006) Antioxidant properties of guava fruit: comparison with some local fruits. Sunway Academic Journal 3: 9-20. 